\title{
Seroprevalence of hepatitis B surface antigenemia and its effects on hematological parameters in pregnant women in Osogbo, Nigeria
}

\author{
Olatunji M Kolawole ${ }^{1 *}$, Abideen A Wahab², Daniel A Adekanle³, Timothy Sibanda ${ }^{1}$ and Anthony I Okoh ${ }^{1}$
}

\begin{abstract}
Background: The transmission of the hepatitis B virus (HBV) is parenteral, sexual and perinatal. Prevention of vertical transmission of HBV is extremely important because HBV infection in early life usually results in a chronic carrier State.

Methods: A descriptive seroepidemiological study of hepatitis B virus and its effects on hematological parameters was investigated in pregnant women attending antenatal clinic of LAUTECH Teaching Hospital, Osogbo, Nigeria. 200 venous samples were subjected to full blood count and its sera were subjected to enzyme-linked immunosorbent assay for the detection of surface antigen of hepatitis B virus.

Results: Prevalence rate of $16.5 \%$ was obtained for hepatitis B surface antigen in pregnant women. The highest HBsAg prevalence rate recorded was $23.3 \%$ for pregnant women between aged 30-34 years while the lowest recorded was zero percent for those aged greater than 40 years. RBC, WBC, neutrophil, hemoglobin lymphocyte and platelet counts have no significant effects on HBsAg positivity of pregnant women $(p=0.801)$. There was no significant difference in $\mathrm{HBsAg}$ positivity in relation to maternal age, gravidity, gestational age, family type, level of education and occupation $(p=0.073)$. Among the potential risk factors, there was significant difference in HBsAg positivity in the pregnant women in relation to their history of HBV vaccination $(p=0.039)$.
\end{abstract}

Conclusions: We advocate universal free screening of pregnant women as the endemicity of HBV infections is thus being propagated.

Keywords: Enzyme-linked immunosorbent assay, Hepatitis B surface antigen, Hematological parameters, Risk factors

\section{Introduction}

Hepatitis B virus (HBV) is a double-stranded DNA virus belonging to Hepadnaviridae family. The incubation period is six weeks to six months [1]. Hepatitis B is a potentially life-threatening liver infection caused by hepatitis $B$ virus. It is a major global health problem and the most serious type of viral hepatitis. It can cause chronic liver disease and put people at high risk of death from cirrhosis of the liver and liver cancer [2]. The primary method of transmission reflects the prevalence of chronic $\mathrm{HBV}$ infection in a given area. In low prevalence areas such as the continental United States and Western

\footnotetext{
*Correspondence: tomak74@yahoo.com

${ }^{1}$ Applied and Environmental Microbiology Research Group (AEMREG),

Department of Biochemistry and Microbiology, University of Fort Hare, Alice, South Africa

Full list of author information is available at the end of the article
}

Europe, where less than $2 \%$ of the population is chronically infected, injection drug abuse and unprotected sex are the primary methods, although other factors may be important [3].

Transmission of hepatitis B virus results from exposure to infectious blood or body fluids containing blood. Possible forms of transmission include (but are not limited to) unprotected sexual contact, blood transfusions, re-use of contaminated needles and syringes, and vertical transmission from mother to child during childbirth [4].

In countries where HBV is highly endemic (hepatitis B surface antigen ( $\mathrm{HBsAg}$ ) prevalence rate of $8 \%$ or higher), most infections occur during infancy and early childhood. Infection occurs commonly in all age groups, although the high rate of chronic infection is primarily maintained by transmission during infancy and early childhood. Where 
endemicity is low (HBsAg prevalence rate of below 2\%), infections occur in young adults, especially those belonging to known risk groups [5].

In areas with high HBV endemicity, perinatal is the main route of transmission. Perinatal transmission is common, especially when HBV infected mothers are also $\mathrm{HBeAg}$ positive . HBeAg - positive mothers are more than $70 \%$ while from $\mathrm{HBsAg}$ - positive, $\mathrm{HBeAg}$ negative mothers, it is less than 10\% [6]. Edmund and colleagues supported this report that without intervention the risk of transmission from an $\mathrm{HBeAg}$ seropositive mother is $70-90 \%$ compare with the risk of about $10 \%$ from an $\mathrm{HBeAg}$ negative mother [7]. Nigeria is highly endemic and the most common circumstance that lead to HBV infection in this population have not been fully elucidated. It has been reported that the exposure rate to HBV (frequency of HBeAg and anti-HBs) ranged from $59 \%$ in children aged under 5 years to $72.5 \%$ in adults aged over 30 years, while the frequency of HBsAg alone was 40 and $10 \%$ respectively [8]. In most epidemiological studies age has always proved to be the most important factor. The age of acquiring infection is the major determinant of the incidence and prevalence rates [9].

Several vaccines has been developed for the prevention of hepatitis B virus infection. These rely on the use of one of the viral envelope proteins (hepatitis B surface antigen or $\mathrm{HBsAg}$ ). The vaccine was originally prepared from plasma obtained from patients who had longstanding hepatitis B virus infection. However, currently these are more often made using recombinant DNA technology, though plasma-derive vaccines continue to be used; the two types of vaccines are equally effective and safe [10]. Following vaccination, hepatitis B surface antigen may be detected in serum for several days; this is known as vaccine antigenemia [11]. Vaccine is generally administered in a two, three or four dose schedules; and can be received by infants to adults. It provides protection for $85-90 \%$ of individuals and lasts for 23 years [12].

Various studies have shown that hematological parameters in pregnancy revealed variation from non-pregnant women [13-15]. Neutrophilia is a feature of pregnancy, while neutropenia is common among non-pregnant Africans [16]. Apart from the hematological changes brought about by hepatitis B infection in the mothers, both perinatal and maternal deaths are substantially increased in hepatitis B infection more especially in under priviledged populations and developing countries [2]. There appears to be a high incidence of low birth weight among infants born to mothers with acute infection during pregnancy [17]. About half of the babies born to mothers who have hepatitis $B$ virus infection during pregnancy will show hepatitis B antigen in their blood and a proportion of them will develop hepatic lesions [18].
A yearly trend of HBsAg seropositivity in North-western Nigeria of $14.6 \%$ in 2004, 10.1\% in 2005, 10.7\% in 2006 and $11.4 \%$ in 2010 have been reported in blood donors [19]. A seroprevalence of $2.4 \%$ in the North-eastern, $2.19 \%, 51.9 \%$ and $4.3 \%$ in the South-western and Southsouthern Nigeria have been reported [20-23]. Recent studies in this locality in blood donors reported 13.5\% HBsAg seropositivity [24]. However, to the best of our knowledge, studies on hepatitis B surface antigenemia in pregnant women have not been reported in this locality. Therefore, this study was aimed at finding the seroprevalence of hepatitis B surface antigenemia and its effects on hematological parameters in pregnant women attending antenatal clinic of LAUTECH Teaching Hospital, Osogbo, Nigeria.

\section{Materials and methods Study area}

The research was carried out in Osogbo City. Osogbo is the capital of Osun state and is centrally situated in Osun State, Nigeria. Ladoke Akintola University Teaching Hospital was chosen as Sample Collection Centre.

\section{Study period}

This study was carried out between December, 2010 and March, 2011.

\section{Sample size}

The Fisher's formula was employed which gives a total of 200 [25].

\section{Subject and samples}

Two hundred pregnant women attending antenatal Clinic of LAUTECH Teaching Hospital, Osogbo in the South-western Nigeria were enrolled into this study after seeking their verbal consent. Ethical consideration approval with a reference number LTH/EC/2010/04/0118 was obtained from the hospital ethical review board. Serum samples were collected from pregnant women by venepuncture and stored frozen in aliquots at $-20^{\circ} \mathrm{C}$ until ready for use.

\section{Socio-demographic data}

Subjects were verbally informed of the study and a questionnaire was administered to obtain socio-demographic information, such as maternal age, gestational age, gravidity, occupation, family type and level of education. Other information on risk factors to possible modes of transmission of HBV, such as history of previous blood transfusions, history of abortions, history of tattooing/tribal marks and history of $\mathrm{HBV}$ vaccination were obtained. 


\section{Blood measurement}

Hematological parameters considered in this study were; White blood cells, Red blood cells, Lymphocyte, Neutrophil, Hemoglobin and platelets. The process of complete blood count was determined by the use of an automated analyzer (Roche Sysmex Xe-2100).

\section{Assays}

HBsAg was detected using third-generation enzyme linked immunosorbent assay (ELISA) kit (Biotech HBsAg device) in accordance with the manufacturer's instructions. A repeat of ELISA test was performed on each positive HBsAg sample, in order to eliminate false positivity after carrying out a neutralization test for each positive test sample detected. Results were finally regarded as positive after a repeated positive ELISA test.

\section{Statistical analysis}

Statistical software JMP version 9 (Generalized linear model) was used for all variables. Comparison were assessed using chi-square and t-test. A p-value of $<0.05$ was considered statistically significant in all statistical comparison.

\section{Results}

Out of 200 sera from pregnant women tested for HBsAg, $33(16.5 \%)$ were positive and 167 (83.5\%) were negative. The highest prevalence of 14 (23.3\%) was recorded in age group of 30-34 years while the lowest of $0(0 \%)$ was recorded in age group greater than 40 years. This difference was not statistically significant $(\mathrm{p}=0.171)$ (Table 1$)$.

Also, the highest prevalence was obtained in multigravid $23(20.7 \%)$ and the least prevalence $10(11.2 \%)$ was obtained in primgravid. There was no significant difference $(p=0.073)$ (Table 2). However, 21 women at their third trimester had $17.4 \%$ prevalence rates while only one woman $20 \%$ at first trimester recorded a low prevalence rate (Table 3).

In considering occupation, the highest prevalence rates was obtained in merchant women $14(12.6 \%)$ and least prevalence was from housewives 0 (0\%). Polygamous family presented highest positivity of HBsAg $(22.2 \%)$ and

Table 1 Prevalence of $\mathrm{HBsAg}$ in relation with the age of pregnant women

\begin{tabular}{|c|c|c|c|c|c|c|c|}
\hline \multirow[t]{2}{*}{ HBsAg } & \multicolumn{6}{|c|}{ Age (years) } & \multirow[t]{2}{*}{ Total } \\
\hline & $15-19$ & $20-24$ & $25-29$ & $30-34$ & $35-39$ & $>40$ & \\
\hline \multirow[t]{2}{*}{ Positive } & 1 & 4 & 13 & 14 & 1 & 0 & 33 \\
\hline & (14.3\%) & $(10.5 \%)$ & (16.9\%) & (23.3\%) & $(6.3 \%)$ & (0\%) & (16.5\%) \\
\hline \multirow[t]{2}{*}{ Negative } & 6 & 34 & 64 & 46 & 15 & 2 & 167 \\
\hline & (85.7\%) & (89.5\%) & (83.1\%) & (76.7\%) & (93.7\%) & $(100 \%)$ & (83.5\%) \\
\hline Total & 7 & 38 & 77 & 60 & 16 & 2 & 200 \\
\hline
\end{tabular}

Table 2 Relationship between gravidity and hepatitis B virus transmission

\begin{tabular}{lccc}
\hline HBsAg & \multicolumn{2}{c}{ Gravidity } & Total \\
\cline { 2 - 3 } & Primgravid & Multigravid & \\
\hline Positive & 10 & 23 & 33 \\
& $(11.2 \%)$ & $(20.7 \%)$ & $(16.5 \%)$ \\
Negative & 79 & 88 & 167 \\
& $(88.8 \%)$ & $(79.3 \%)$ & $(83.5 \%)$ \\
Total & $\mathbf{8 9}$ & $\mathbf{1 1 1}$ & $\mathbf{2 0 0}$ \\
\hline $\mathrm{X}^{2}=3.2516$ & P-value $=0.0714 \quad \mathrm{df}=1$. & &
\end{tabular}

(15.9\%) recorded in monogamous family. Considering the level of education, the highest seropositivity of HBsAg 17 (17.2\%) was obtained in women that had tertiary education while the lowest seropositivity of HBsAg 7 (25\%) was recorded in women with primary education. There was no significant difference $(\mathrm{p}=0.298)$ (Table 4).

The hematological indices (Table 5) of the pregnant women revealed that lymphocyte, RBC, WBC, neutrophil, hemoglobin and platelet counts were statistically non-significant with $\mathrm{HBsAg}$ positivity in the pregnant women $(\mathrm{p}=0.51,0.50,0.49,0.49,0.51$ and 0.48 respectively).

Of those (71) with tattooing and tribal marks, $12.7 \%$ were HBsAg positive while there was none positive to HBsAg with history of previous blood transfusion. 5.4\% were positive to $\mathrm{HBsAg}$ in those with history of abortion while $37.5 \%$ of those with history of HBV vaccination were positive to $\mathrm{HBsAg}$ in the pregnant women $(\mathrm{p}=0.039)$.

\section{Discussion}

Screening asymptomatic people is an important instrument in disease detection, prompt diagnosis and intervention, particularly at an early stage of the disease. This may improve the health outcome as well as better understanding of the transmission pattern of the disease [26]. In Asia and sub-Saharan Africa, HBV infection is endemic and thought to be the main etiological factor in over $75 \%$ of the chronic liver disease [24]. The results from this present study in Osogbo, Nigeria, revealed a

Table 3 Relationship between gestational age and hepatitis $B$ virus transmission

\begin{tabular}{lcccc}
\hline HBsAg & \multicolumn{3}{c}{ Gestational age } & Total \\
\cline { 2 - 4 } & $\mathbf{1}^{\text {st }}$ trimester & $\mathbf{2}^{\text {nd }}$ trimester & $\mathbf{3}^{\text {rd }}$ trimester & \\
\hline Positive & 1 & 11 & 21 & 33 \\
& $(20 \%)$ & $(14.9 \%)$ & $(17.4 \%)$ & $(16.5 \%)$ \\
Negative & 4 & 63 & 100 & 167 \\
& $(80 \%)$ & $(85.1 \%)$ & $(82.6 \%)$ & $(83.5 \%)$ \\
Total & $\mathbf{5}$ & $\mathbf{7 4}$ & $\mathbf{1 2 1}$ & $\mathbf{2 0 0}$ \\
\hline $\mathrm{X}^{2}=0.2525$ & P-value $=0.881 \mathrm{df}=2$. & & &
\end{tabular}


Table 4 Relationship between socio-demographic characteristics of pregnant women with hepatitis B virus transmission

\begin{tabular}{|c|c|c|c|c|c|c|}
\hline \multirow[t]{3}{*}{$\mathrm{HBsAg}$} & \multicolumn{2}{|c|}{ P-value $=0.0913$} & \multicolumn{2}{|c|}{$X^{2}=8.006 \mathrm{df}=4$} & & \\
\hline & \multicolumn{6}{|c|}{ Occupation } \\
\hline & Civil Servant & Student & Housewife & Merchant & Medical Personnel & Total \\
\hline \multirow[t]{2}{*}{ Positive } & 12 & 3 & 0 & 14 & 4 & 33 \\
\hline & $(20.7 \%)$ & $(16.7 \%)$ & $(0 \%)$ & $(12.6 \%)$ & $(44.4 \%)$ & $(16.5 \%)$ \\
\hline \multirow[t]{2}{*}{ Negative } & 46 & 15 & 4 & 97 & 5 & 167 \\
\hline & $(79.3 \%)$ & (83.3\%) & $(100 \%)$ & (87.4\%) & $(55.6 \%)$ & $(83.5 \%)$ \\
\hline \multirow[t]{4}{*}{ Total } & 58 & 15 & 4 & 111 & 9 & 200 \\
\hline & \multicolumn{2}{|c|}{ P-value $=0.493$} & \multicolumn{2}{|c|}{$X^{2}=0.4707 \mathrm{df}=1$} & & \\
\hline & \multicolumn{6}{|c|}{ Family Type } \\
\hline & Monogamy & & Polygamy & & & Total \\
\hline \multirow[t]{2}{*}{ Positive } & 29 & & 4 & & & 33 \\
\hline & (15.9\%) & & (22.2\%) & & & $(16.5 \%)$ \\
\hline \multirow[t]{2}{*}{ Negative } & 153 & & 14 & & & 167 \\
\hline & (84.1\%) & & (77.8\%) & & & $(83.5 \%)$ \\
\hline \multirow[t]{4}{*}{ Total } & 182 & & 18 & & & 200 \\
\hline & \multicolumn{2}{|c|}{$\mathrm{P}$-value $=0.2956$} & \multicolumn{2}{|c|}{$X^{2}=2.4374 d f=2$} & & \\
\hline & \multicolumn{6}{|c|}{ Education } \\
\hline & Primary & & Post-Primary & & Tertiary & Total \\
\hline \multirow[t]{2}{*}{ Positive } & 7 & & 9 & & 17 & 33 \\
\hline & $(25 \%)$ & & (12.3\%) & & $(17.2 \%)$ & $(16.5 \%)$ \\
\hline \multirow[t]{2}{*}{ Negative } & 21 & & 64 & & 82 & 167 \\
\hline & $(75 \%)$ & & (87.7\%) & & $(82.8 \%)$ & $(83.5 \%)$ \\
\hline Total & 28 & & 73 & & 99 & 200 \\
\hline
\end{tabular}

seroprevalence rates of $16.5 \%$, this lies within the established standard that West African countries have moderate to high hepatitis $\mathrm{B}$ endemicity as reported elsewhere $[27,28]$. High prevalence of $12 \%$ was reported among a similar study population in Taiwan and $10 \%$ in Hong Kong [29]. In Ilorin, prevalence rate of $5.7 \%$ was reported in mothers and $10 \%$ in their preschool age children [30]. In Benin city, a 2.19\% maternal HBsAg seroprevalence have been reported [21].

Table 5 Relationship of hematological indices of the pregnant women with hepatitis B virus transmission

\begin{tabular}{lccc}
\hline Parameter & \multicolumn{3}{c}{ HBsAg \pm SEM } \\
\cline { 2 - 4 } & Positive & P-value & Negative \\
\hline Hemoglobin $(\mathrm{g} / \mathrm{dl})$ & $10.08 \pm 1.00$ & $\mathbf{0 . 5 1}$ & $10.03 \pm 1.28$ \\
Red blood cell $(\mathrm{K} / \mu \mathrm{l})$ & $3.70 \pm 0.47$ & 0.50 & $3.72 \pm 0.61$ \\
White blood cell $(\mathrm{K} / \mu \mathrm{l})$ & $6.70 \pm 1.63$ & 0.49 & $6.78 \pm 1.78$ \\
Platelet $(\mathrm{K} / \mu \mathrm{l})$ & $182.52 \pm 53.41$ & 0.48 & $188.41 \pm 55.49$ \\
Neutrophil $(\mathrm{K} / \mu \mathrm{l})$ & $4.20 \pm 1.57$ & 0.49 & $4.31 \pm 1.40$ \\
Lymphocyte $(\mathrm{K} / \mu \mathrm{l})$ & $1.86 \pm 0.50$ & 0.51 & $1.78 \pm 1.52$ \\
\hline
\end{tabular}

The results indicated that the prevalence was high among 30-34 age-groups than others (Table 1). This correlates with the peak age of highest sexual activity in the society, hence supporting the role of sexual intercourse in the transmission of hepatitis B virus. The result also agrees with the report of Aganga [31] that in populations in which hepatitis B virus is relatively common; the majority of infections and peak prevalence of HBsAg as well as of specific antibody were in the age -group 25-29 and 30-34 years. There was no significant difference between age-groups as they relate to HBsAg prevalence $(p=0.171)$, therefore establishing the fact that HBV is common in all age-groups of life. However, the findings disagrees with the work of [32] in the same locality who reported highest HBsAg seroprevalence in blood donors of ages above 58 years.

The high prevalence of HBsAg in multigravids (20.7\%) compared to primgravid (11.2\%) might possibly be due to longer period of marriage and multiple deliveries in the locality (Table 2). This is in consonance with the report of Aganga [31] that women with longer period of marriage might have greater sexual activities and 
Table 6 Potential risk factors and prevalence of HBsAg among the pregnant women

\begin{tabular}{|c|c|c|c|c|c|c|}
\hline \multirow[t]{2}{*}{$\mathrm{HBsAg}$} & \multicolumn{5}{|c|}{ Risk factor } & \multirow{2}{*}{$\begin{array}{c}\text { Total } \\
(\%)\end{array}$} \\
\hline & $\begin{array}{l}\text { Tattooing/tribal } \\
\text { marks (\%) }\end{array}$ & $\begin{array}{l}\text { History of previous blood } \\
\text { transfusion (\%) }\end{array}$ & $\begin{array}{c}\text { History of } \\
\text { abortion (\%) }\end{array}$ & $\begin{array}{l}\text { History of HBV } \\
\text { vaccination (\%) }\end{array}$ & $\begin{array}{l}\text { No risk factor } \\
\text { (\%) }\end{array}$ & \\
\hline Positive & $9(12.7)$ & $0(0)$ & $2(5.4)$ & $3(37.5)$ & $19(23.7)$ & $\begin{array}{c}33 \\
(16.5)\end{array}$ \\
\hline Negative & 62 (87.3) & $4(100)$ & 35 (94.6) & $5(62.5)$ & $61(76.3)$ & $\begin{array}{c}167 \\
(83.5)\end{array}$ \\
\hline Total & 71 & 4 & 37 & 8 & 80 & 200 \\
\hline
\end{tabular}

$\mathrm{X}^{2}=10.7460$ P-value $=0.0296 \mathrm{df}=4$.

multiple deliveries, thereby exposing them to risk of HBV infection. There is a corresponding increase in HBsAg with an increase in the gestational age (Table 3). This might possibly be explained from the fact that pregnancy progresses with an attendant decrease in immunity of the expectant mother [33] a reason that might have given more chances to the virus to have undergone multiplication, a process that could result in the production of more HBsAg in the mother's blood. There was no statistical significance of HBsAg positivity with gestatational age $(\mathrm{p}=0.881)$. The high prevalence indicated among merchant women and those with tertiary education (Table 4), might possibly be explained by their high level of exposure and interaction with opposite sex. This could lead to having heterosexual partner, and this is one of the most important mode of transmission of HBV [34].

The risk factors identified in this study were tattooing / tribal marks, history of previous blood transfusion, history of abortion and history of $\mathrm{HBV}$ vaccination (Table 6). These findings are not unexpected since epidemiological studies have consistently demonstrated that transfusion of unscreened blood and blood products, and socio-cultural practices, such as circumcision and scarification, are important routes of transmission of HBV infection [35]. These socio-cultural practices are often done by the use of scientifically unsterilized devices. It is therefore plausible to suggest that engagement in these activities could have exposed the HBsAgpositive pregnant women to $\mathrm{HBV}$ infection initially. None of the pregnant women with history of previous blood transfusion were positive to HBsAg. This is not surprising as it is a national policy that all blood must be screened for HBsAg before transfusion in hospitals [32]. However, the significant association between HBsAg seropositivity in pregnant women in this study and history of previous $\mathrm{HBV}$ vaccination is in conformity with the findings by Alter and colleagues [36] who reported that no recognizable risk factor could be ascribed to $30 \%$ of cases of HBV infection in adults.

Out of the six hematological indices analyzed in this study, lymphocytes concentration were increased when compared with negative HBsAg pregnant women, though not statistically significant $(\mathrm{p}=0.51)$. This could possibly be explained from the fact that the lymphocyte, which is one of the indices of white blood cells in combating diseases, is raised in the presence of viral infections [37]. However, this could be adduced to immunosuppressive status of women in pregnancy. The significant increased could also be aggravated by a dual infections in the pregnant women. HIV-HBV co-infected Nigerians have been reported to have lower CD4+ T-cell counts compared to HIV mono-infected individuals [38]. Several studies on HBV mono-infection support the idea that HBV leads to an overall increase in T-cell activation $[39,40]$.

The major strength of this study is that to the best of our knowledge, this is the first report of seroprevalence of HBsAg and its effect on hematological indices of pregnant women in Osogbo and in the South-western part of Nigeria, a country known with high HBV endemicity. A limitation of this study is that we do not have data on opportunistic infections in the pregnant women prior to study entry.

In summary, in order to interrupt the cycle of transmission of HBV in Nigeria through perinatal route, these strategies would be recommended; free regular blood screening, public education, behavioural modification, passive immunoprophylaxis and active immunization.

\section{Conclusions}

It is clear from this study that Nigeria is in the region with high prevalence of HBV. There are many unvaccinated women in childbearing age who are at risk of HBV infection. It is important to note that infection by HBV early in life underscores the potential of adding to the burden of viral hepatitis and its attending complication of hepatocellular carcinoma later in life.

\section{Competing interest}

We wish to state that there are no actual or potential conflict of interest including any financial, personal or other relationships with other people or organizations that could inappropriately influence, or be perceived to influence, this work.

\section{Authors' contributions}

OMK and AAW participated in the design of the study and performed the investigation, analysis and interpretation of data. DAA participated in sample 
collection and administration of questionnaires. AlO participated in the design and coordination. OMK, AAW and TS drafted the manuscript. All authors read and approved the final manuscript.

\section{Acknowledgements}

We wish to appreciate the management of Ladoke Akintola University of Technology Teaching Hospital for their approval to carry out the study.

\section{Author details}

${ }^{1}$ Applied and Environmental Microbiology Research Group (AEMREG), Department of Biochemistry and Microbiology, University of Fort Hare, Alice, South Africa. ${ }^{2}$ Department of Biological Sciences, Osun State University, P.M.B 4494, Osogbo, Nigeria. ${ }^{3}$ Department of Obstetrics and Gynaecology, LAUTECH Teaching Hospital, Osogbo, Nigeria.

Received: 22 November 2011 Accepted: 17 December 2012 Published: 27 December 2012

\section{References}

1. CDC: Sexually transmitted diseases treatment guidelines. MMWR Recomm Rep 2002, 51(RR-6):1-78.

2. WHO: Advanced immunization management. Hepatitis. Fact sheet $N^{0} ; 2005$.

3. Redd HT, Baunbach H, Kohn W: Patient to patient transmission of hepatitis B virus associated with oral Surgery. J infect Dis 2007, 195(9):1311-4

4. CDC: Hepatitis transmitted by a human bite: Morb. Mort. Wkly Rep; 1974:23-24.

5. ACIP: Protection against viral hepatitis: recommendation of the immunization practices advisory committee. Morb Mort Wkly Rep 1990 39(RR-2)

6. Nacos B, Dao B, Dahourou M, et al: HBs antigen carrier state in pregnant women in Bobo Dioulasso (Burkinafaso). Dakar Med 2000, 42(2):188-190.

7. Edmund WJ, Medley GF, Nokes DJ, O'Callaghan CJ, Whittle HC, Hall AJ: Epidemiological patterns of hepatitis $B$ virus (HBV) infection in highly endemic areas. Epidemiol Infect 1996, :313-325.

8. Fakunle YM, Abdulraham MB, Whittel HC: Hepatitis B virus infection in children and adults in northern Nigeria: a preliminary survey. Trans $R$ SOC Trop Med Hyg 1981, 75(5):625-629.

9. Christy NE, Dennis EA, Gilbert ON, et al: The seroprevalence of hepatitis B surface antigen and human immunodeficiency virus among pregnant women in Anambra State, Nigeria. Shtraz E-medical J 2004, 5(2):1-25.

10. Zuckerman JN: Vaccination against hepatitis A and B: development deployment and elusion. Curr Opin Infect Dis 2006, 19(5):456-9.

11. Martin-Ancel A, Casas ML, Bonet B: Implication of Post vaccination hepatitis $B$ surface antigenemia in the management of exposure to body fluids. Infect control Hosp Epidemiol 2004, 25(7):611-3.

12. MCS: Mayo Clinic Staff. Hepatitis B prevention. Mayo Clinic: http:www.mayoclinic.com/health/hepatitis B/DS.

13. Onwukeme KE, Uguru VE: Haematological values in pregnancy in Jos. West Afr J Med 1990, 9:70-75.

14. Osoagbaka OU, Haruna RH, Anokwuru OC: Observation on some hematological parameters of Nigerian women during pregnancy. $J$ Med Invest Pract 2000, 1:45-48.

15. Kei N: Pregnancy and the erythrocyte sedimentation rate. J Immune Based Therapies Vaccines 2004, 2(4):45-57.

16. Arinola OG, Obisesan K, Salimonu LS, Onifade R, Afolabi K: Leucocyte phagocytosis and circulation immune complexes in mothers after child birth. West Afr J Med 2004, 23:256-9.

17. Pavel A, Tirsia E, Maior E, Cristea A: Detrimental effects of hepatitis B virus infection on the development of product of conception. Virologie 1983, 34:34-40.

18. Tse KY, Lo LF, Lao T: The Impact of maternal HBsAg carrier status on pregnancy outcomes: A case-control study. J Hepatol 2005, 43:371-75.

19. Nwokedi E, Odimayo MS, Emokpae AM, Yahaya IA, Sadiq MN, Okwori EE: Seroprevalence of hepatitis B surface antigen among patients attending Aminu Kano Teaching Hospital. Kano Niger J Med 2010, 19(4):423-6.

20. Olokoba AB, Salawu FK, Danburam A, Desalu OO, Olokoba LB, Wahab KW, Badung LH, Tidi SK, Midala J, Aderibigbe S, Abdulrahman MB, Babalola OM, Abdukkarim A: Viral hepatitides in voluntary blood donors in Yola, Nigeria. Euro J Sci Res 2009, 31(3):329-334.
21. Onakewhor JUE, Offor E, Okonofua FE: Maternal and neonatal seroprevalence of hepatitis B surface antigen ( $\mathrm{HBsAg}$ ) in Benin city, Nigeria. J Obs Gynaecol 2001, 21(6):583-586.

22. Iwalokun BA, Hodonu SO, Olaleye BM, Olabisi OA: Seroprevalence and biochemical features of hepatitis $B$ surface antigenemia in patients with HIV-1 infection in Lagos. Afri J Med Med Sci 2006, 35(3):337-43.

23. Ajayi AO, Komolafe AO, Ajumobi K: Seroprevalence of hepatitis B surface antigenemia among health care workers in a Nigerian tertiary health institution. Niger J Clin Pract 2007, 10(4):287-9.

24. Dawaki SS, Kawo AH: Seroprevalence of hepatitis B Surface antigen among pregnant women. Nig J Microbiol 2006, 20(1):705-709.

25. Araoye MO: Sample size determination. Research methodology with statistics for health and social sciences: 2003:118-121.

26. Isselbacher KJ, Wands JR: Neoplasms of the liver. In Harrison's Principle of Internal Medicine (12 ${ }^{\text {th }}$ Edition). Edited by Wilson JD, Braunwald E, Isselbacher K, et al. New York, USA: McGraw-Hill; 1991:1350-1352.

27. Miren B, Asun S, Mario S, Enrigue G, Iboy DO, Ramon C: Seroprevalence of hepatitis $B$ and $C$ and human immunodeficiency type 1 virus in a rural population from the Republic of Equatorial Guinea. Trans R Soc Trop Med Hyg 1999, 93:250-252.

28. Awosere KE, Arinola OG, Uche $L N$ : Hepatitis $B$ virus seroprevalence among pregnant women. J Med Lab Sc 1999, 3(2):23-27.

29. Kong KL, Cho Y, Lee SS: The declining HBsAg carriage rate in pregnant women in Hong Kong. Epidemiol Infect 1997, 199:281-283.

30. Agbede OO, Iseniyi JO, Kolawole OM, Ojuawo A: Risk factors and Seroprevalence of hepatits B surface antigenemia in mothers and their pre-school age children in Ilorin, Nigeria. Future Med Therapy 2007, 4(1):67-72.

31. Aganga WOM, Akanmu AS, Akinsete A, Njoku OS: Prevalence of hepatitis B surface antigen among women of childbearing age. Afr J Rep 1999, 3(1):45-50.

32. Opaleye $\mathrm{OO}$, Zakariyahu TO, Tijani BA, Bakarey AS: HBV, HCV co-infection among blood donors in Nigeria. Indian J Pathol Microbiol 2010, 53:182-3.

33. Soxhami RL, Moxhan J: Textbook of Medicine (1 $1^{\text {st }} \mathrm{Ed}$ ). Churchill Livingstone city, United Kingdom: Longman Group Publishers; 1991:634-635.

34. Duncan ME, Tibaus G, Pelger A: Prevalence and significance of sexually transmitted diseases among women. Ethiop J Health Dev 1995, 9:31-40.

35. Maddawa V, Burgress C, Drucker E: Epidemiology of Chronic Hepatitis C infection in sub-Saharan Africa. Lancet Infect 2002, 2:293-302.

36. Alter HJ, Blumberg BS: Further studies on a new human isoprecipitin system (Australia antigen). Blood 1966, 27(3):297-309.

37. Shale MJ: The implications of anti-tumour necrosis factor therapy for viral infection in patients with inflammatory bowel disease. Br Med Bull 2009, 92(1):61-77.

38. Idoko J, Meloni S, Muazu M, Nimzing L, Badung B, Hawkins C, Sankale J, Ekong E, Murphy R, Kanki P, Thio CL: Impact of hepatitis B virus infection on HIV response to antiretroviral therapy in Nigeria. Clin Infect Dis 2009, 49(8):1268-1273.

39. Nakamura K, Yuh K, Sugyo S, Shijo H, Kimura N, Okumura M: Apoptosis observed in peripheral T lymphocytes from patients with chronic hepatitis B. Gastroenterology 1996, 111:156-164.

40. Raptopoulou-Gigi M, Orphanou-Koumerkeridou H, Lagra F: Possible mechanisms underlying peripheral lymphocyte activation in chronic liver disease and asymptomatic HBsAg carriers. Allergol Immunopathol (Madr) 1989, 17:145-148.

doi:10.1186/1743-422X-9-317

Cite this article as: Kolawole et al:: Seroprevalence of hepatitis B surface antigenemia and its effects on hematological parameters in pregnant women in Osogbo, Nigeria. Virology Journal 2012 9:317. 